Dorota Drałus

Uniwersytet Wrocławski

\title{
Endemiczność konfliktu, nieuchronność polityki
}

DOI: $10.19195 / 1643-0328.22 .6$

Słowa kluczowe: definicja polityki, konflikt polityczny, metapolityczność

\section{Depolityzacja konfliktu}

W celu uzasadnienia tezy o nieuchronności polityki i jej koniecznym związku z konfliktem społecznym pomocne jest odwołanie się do bardzo swoistego sposobu rozumienia polityczności, jakie można znaleźć na gruncie marksizmu. Odpowiedź, jakiej udziela marksizm, na pytanie o polityczność jest szczególnie interesująca poznawczo i metodologicznie, ponieważ jest tak bardzo odmienna od tradycyjnych koncepcji teoretyczno-politycznych, że w istocie można powiedzieć, iż sytuuje się ona poza spektrum koncepcji teoretyczno-politycznych w ogóle ${ }^{1}$.

Konfrontacja ze specyficzną i utopijną marksistowską koncepcją polityczności, po pierwsze, posłuży wykazaniu, że polityczność, jako nieodłączny przymiot zbiorowisk ludzkich, z konieczności odnosi się do konfliktowości jako zjawiska endemicznego dla każdej struktury społecznej. Po drugie, pozwoli wskazać na nietrafne utożsamienie polityczności ze specyficzną formą zarządzania społecznego, jaką jest państwowość, takim bowiem rozumieniem polityczności posługiwał się Karol Marks. Rozumienie polityczności zawężone do sfery zarządzania wydaje się zbyt wąskie. Konfrontacja z marksizmem umożliwi wykazanie słuszności znacznie szerszego rozumienia polityczności, takiego, które przejawia się nie tylko w zarządzaniu struktur i instytucji państwowych. Jakkolwiek tak właśnie najczęściej pojmuje się politykę w świadomości potocznej, to celem niniejszego studium jest wykazanie, iż polityka jest nieuchronnie obecna zarówno na płaszczyźnie mikrostruktur społecznych, jak i makrostruktur, tj. zbiorowości i instytucji ponadpaństwowych.

1 A. Callinicos, Marxism and Politics, [w:] What is Politics? The Activity and Its Study, red. A. Leftwich, Cambridge 2004, s. 53. 
Według Alexa Callinicosa tym, co jest być może najistotniejsze w podejściu marksistowskim do polityki, jest fakt, że doktryna ta zaprzecza, iżby polityka była trwałą cechą każdej formy społecznej. Jak stwierdza: „Marksizm kwestionuje podstawowe założenie leżące u podstaw dyscypliny politologii, to mianowicie, że istnieje trwała i autonomiczna cecha społeczeństwa zwana polityką" ${ }^{2}$. Teza ta jest interesująca przede wszystkim dlatego, że doktryna marksistowska podkreśla ze szczególną mocą konfliktowość życia społecznego; mimo to przedstawiciele marksizmu zaprzeczają zachodzeniu ścisłego związku między konfliktem a polityką. Punktem wyjścia do zrozumienia przyjętej na gruncie marksizmu rozdzielności konfliktu i polityki jest zrozumienie samego pojęcia polityki, obowiązującego na gruncie tej doktryny. Jak wiadomo, marksizm stoi na gruncie radykalnej historyczności wszelkich form społecznych. Marks argumentował, że historia wszystkich znanych dotychczas społeczeństw jest w istocie historią walk i konfliktów klasowych. Na gruncie holistycznej teorii marksistowskiej, zwanej materializmem historycznym, konflikt, przemoc i władza w nieuchronny sposób odnoszą się do pojęcia państwa. Państwo samo jest instytucją ukształtowaną historycznie w rezultacie pojawienia się podziału klasowego. Na podstawie analiz historycznych Marks argumentował, że pojawienie się polityki oraz jej transformacje wskazują na jej konieczny związek z podziałem klasowym społeczeństwa, konfliktem klas i państwa, które ma charakter klasowy, albowiem powstało jako instrument służący interesom posiadaczy, oraz, co jest drugą stroną tej samej sprawy, jest instrumentem opresji klas uciśnionych.

Jakkolwiek Marks i jego zwolennicy podkreślają, iż konfliktowość jest endemiczną cechą każdej formy społecznej, to zarazem są przekonani, iż polityka nie jest nieuchronną cechą struktur społecznych i że jest przymiotem wyłącznie państwa jako formy zarządzania społeczeństwem klasowym. Marksowski materializm historyczny sprzeciwia się przekonaniu, że skoro konflikt między rywalizującymi grupami ma charakter endemiczny dla ludzkiego społeczeństwa, to nieuchronnie będzie on generować politykę bez względu na możliwe przeobrażenia urządzeń ekonomicznych i społecznych ${ }^{3}$. Callinicos uważa, że

jeżeli polityka jest wytworem antagonizmu klasowego, to jest zjawiskiem historycznie ograniczonym pod dwoma względami. Polityka nie tylko ma względnie niedawne pochodzenie, ale także nie będzie w stanie przetrwać eliminacji antagonizmów klasowych ${ }^{4}$.

Z perspektywy marksistowskiej procesy podejmowania decyzji politycznych postrzegane są jako dotyczące instytucji państwa. Callinicos podkreśla w tym kontekście zgodność między marksizmem a klasyczną definicją Maxa Webera:

państwo jest ostatecznie instytucją opartą na przemocy, zależną od monopolu prawomocnej władzy na określonym terytorium. Natomiast konflikty między różnymi grupami [w danym społeczeństwie] zazwyczaj skupiają się wokół problemów przejęcia władzy lub wpływania na sposób jej sprawowania. Tym samym polityka w nieuchronny sposób jest skojarzona z istnieniem państw ${ }^{5}$.

\footnotetext{
${ }^{2}$ Ibidem, s. 54.

3 Ibidem, s. 61.

${ }^{4}$ Ibidem.

5 Ibidem, s. 68.
} 
By ponownie podkreślić, zgodnie z przewidywaniem Marksa o historycznej konieczności obalenia podziałów klasowych w rezultacie rewolucji proletariackiej, że państwo jako aparat opresji zostanie zniesione, a tym samym zniesieniu ulegnie również polityka.

\section{Metapolityczność}

Marksistowskie podejście do polityki kontynuuje współczesna postmarksowska teoria polityczna, m.in. Jacques Rancière ${ }^{6}$ oraz Slavoj Žižek. Punktem wyjścia rozważań Rancière’a na temat relacji między konfliktem i polityką jest jego specyficzne pojmowanie polityki. Definicję tę podsumował Žižek następująco:

Polityka właściwa zawsze implikuje... swego rodzaju zwarcie między tym, co Uniwersalne a tym, co Partykularne: implikuje paradoks czegoś jednostkowego, które przedstawia się jako zastępnik tego, co Uniwersalne, destabilizując "naturalny” porządek funkcjonalny stosunków panujących w ciele społecznym. Właściwa walka polityczna więc nigdy nie jest po prostu racjonalną debatą między wieloma rozmaitymi interesami, lecz jest jednocześnie walką o wysłuchanie swojego głosu i uznanie go za głos prawomocnego partnera. Kiedy „wykluczeni” - poczynając od greckiego demosu na polskich robotnikach kończąc - protestowali przeciwko rządzącej elicie (przeciwko arystokracji lub nomenklaturze), prawdziwą stawką nie były ich otwarcie formułowane żądania (wyższych płac, poprawy warunków pracy, itp.), lecz samo ich prawo do głosu i do uznania za równego partnera w debacie; w Polsce nomenklatura przegrała $\mathrm{z}$ chwilą, gdy musiała uznać Solidarność za równego partnera... Cała historia myśli politycznej jest ostatecznie szeregiem zaprzeczeń tego politycznego momentu, właściwej logiki antagonizmu politycznego ${ }^{7}$.

Ilustrując ten sposób pojmowania polityki i jej teoretycznych konceptualizacji, Žižek przytacza wyróżnione przez Rancière’a wersje teoretyczno-politycznych „zaprzeczeń” konfliktowości społecznej, przejawiającej się w formie antagonizmu politycznego. Odpowiednio do tego mamy do czynienia z kilkoma typami politycznego zamazywania antagonizmu politycznego. Jednym z nich jest archepolityka, którą Rancière utożsamia z Platońską koncepcją państwa ${ }^{8}$. Innym jest parapolityka, tj. unicestwienie polityki poprzez eliminację konfliktu, zaproponowane przez Thomasa Hobbesa. Trzecim typem podejścia do relacji między konfliktem i polityką jest ultrapolityczna koncepcja Carla Schmitta; na jej gruncie dokonuje się redukcja konfliktu politycznego do konfliktu militarnego, polityka jest zaś ostatecznie rozumiana jako kontynuacja wojny innymi środkami. Czwartym sposobem teoretycznego odniesienia się do konfliktu jest właśnie marksistowskie pojmowanie polityki, tj. koncepcja, która dokonuje zatarcia swoistości konfliktu politycznego, postrzegając go jako pochodną konfliktów dziejących się na bardziej fundamentalnym poziomie społecznym, a mianowicie w sferze ekonomicznej. Stanowisko to Rancière określa mianem metapolitycznego.

Proponując ten nowy termin, Rancière wyraża ideę, zgodnie z którą Marksowskie metapolityczne pojmowanie konfliktów społecznych ujawnia je jako konflikty auten-

\footnotetext{
6 J. Rancière, Dis-Agreements. Politics and Philosophy, przeł. na ang. J. Rose, Minneapolis-London 1999.

7 S. Žižek, Przekleństwo fantazji, przeł. A. Chmielewski, Wrocław 2001, s. 89-90.

8 J. Rancière, op. cit., s. 65.
} 
tyczne, podczas gdy płaszczyzna polityki jest ich zaledwie nieautentycznym, zafałszowanym odbiciem. Według Rancière’a zatem

metapolityka ujawnia radykalny nadmiar niesprawiedliwości lub nierówności w relacji do tego, co polityka przedstawia jako sprawiedliwość lub równość. Orzeka absolutną krzywdę, nadmiar krzywdy, która niweczy jakiekolwiek posłużenie się argumentem równości. Za pomocą tego nadmiaru, ujawnia ona również „prawdy” polityki. Lecz prawda ta jest szczególnego rodzaju. Nie jest nią jakaś idea dobra, sprawiedliwości, boskiego kosmosu lub prawdziwej równości, która umożliwiłaby powstanie realnej wspólnoty w miejsce politycznego kłamstwa. Prawda polityki jest manifestacją jej fałszywości ${ }^{9}$.

Objaśniając to stanowisko, Žižek stwierdza, że na gruncie marksistowskiej lub utopijno-socjalistycznej metapolityki

konflikt polityczny jest... w pełni uznany, ALE jedynie jako teatr cieni, gdzie odgrywane są zdarzenia, których właściwym miejscem jest Inna Scena (procesów ekonomicznych); ostatecznym celem "prawdziwej” polityki jest więc samoobalenie, transformacja „administrowania ludźmi” w „administrowanie rzeczy” w ramach całkowicie przejrzystego, racjonalnego porządku Woli zbiorowej. (Mówiąc ściślej, marksizm jest pod tym względem ambiwalentny, ponieważ sam termin „ekonomia polityczna” otwiera również przestrzeń dla gestu przeciwnego, polegającego na wprowadzeniu polityki do samego serca ekonomii, czyli dla odrzucenia „apolitycznego" charakteru procesów ekonomicznych jako skrajnego ideologicznego złudzenia. Walka klasowa nie „wyraża” określonych obiektywnych sprzeczności ekonomicznych, jest ona bowiem formą samego istnienia tych sprzeczności. ${ }^{10}$.

W swojej interpretacji Marksowskiego rozumienia polityki jako metapolityki Rancière wielokrotnie odwołuje się do języka ocen moralnych. Głosi on, że fałsz polityki ma zasadniczo charakter moralny i polega on na tym, iż polityka zaciera i zamazuje to, co jest największym skandalem rozmaitych form życia społecznego, mianowicie wyzysk, nierówność i rozziew w samym człowieczeństwie, tj. alienację człowieka od siebie samego. W opinii Rancière’a tej

metapolitycznej wersji owego rozziewu między człowiekiem i obywatelem, między ludem pracującym i ludem suwerennym, przeciwstawia się wersję polityczną. Dla polityki fakt, że ludzie są wewnętrznie rozdarci, nie jest $\mathrm{w}$ istocie skandalem, nad którym trzeba ubolewać. Jest on bowiem pierwotnym warunkiem uprawiania polityki ${ }^{11}$.

Przy takiej ocenie funkcjonowania sfery politycznej, stanowiącej jedynie zafałszowane odbicie realnych konfliktów dziejących się na płaszczyźnie bazy społeczno-ekonomicznej, zrozumiała i moralnie uzasadniona jest dążność do obalenia polityki, która jest ich ideologicznie zniekształconym odzwierciedleniem w nadbudowie. Cel ludzkiej aktywności według Marksa ma charakter moralny i jest nim wszechstronny rozwój człowieka, nie zaś wyłącznie wąsko rozumiana „emancypacja polityczna”, którą surowo krytykował w znanym tekście $W$ kwestii żydowskiej ${ }^{12}$.

Wypracowane przez Rancière’a stanowisko skłania go również do negatywnej oceny tezy o końcu historii, sformułowanej przez Francisa Fukuyamę ${ }^{13}$. Ogłaszając w 1989 r.

${ }^{9}$ Ibidem, s. 81-82.

10 Ibidem.

11 Ibidem, s. 87.

12 K. Marks, W kwestii żydowskiej, [w:] K. Marks, F. Engels, Dzieła, t. 1, Warszawa 1960.

13 Por. F. Fukuyama, Koniec historii, przeł. T. Bieroń, M. Wichrowski, Poznań 1996; idem, Ostatni człowiek, przeł. T. Bieroń, Poznań 1997. 
historyczne zwycięstwo liberalnej demokracji, Fukuyama postrzegał ją jako zwieńczenie historycznych poszukiwań najlepszego z możliwych ustrojów. Rancière uznaje, że:

Koniec polityki, ogłoszony u kresu policyjnego marksizmu, jest... jedynie inną postacią, „liberalną” kapitalistyczną postacią marksowskiej metapolityki. Kres polityki jest ostateczną fazą metapolitycznej interferencji, ostateczną afirmacją pustki jej prawdy. Koniec polityki jest spełnieniem filozofii politycznej ${ }^{14}$.

Innymi słowy, marksistowskie rozumienie polityki jako czegoś nieautentycznego, jako czegoś, co znajduje się „poza" 15 realnym życiem społecznym, prowadzi do kolejnej tezy o oderwaniu polityki od życia społecznego oraz jej niekonieczności. Filozofia polityki z natury rzeczy ogranicza swoje zadanie teoretyczne; zniesienie polityki oznacza zatem również zniesienie i kres samej filozofii politycznej.

\section{Wszechobecność polityki}

W swoim studium teoretyczno-politycznym Adrian Leftwich formułuje tezę, że nie można rozumieć polityki jako aktywności ludzkiej ograniczonej tylko do jej związków z instytucjami publicznymi, zajmującymi się procesami i praktykami rządzenia państwem lub zarządzaniem i formułowaniem polityk publicznych. Uznając takie podejście za nieuzasadnione, Leftwich proponuje następującą definicję polityki:

Polityka obejmuje wszystkie aktywności współpracy, negocjacji i konfliktu w ramach społeczeństw i między nimi, w których ludzie wykorzystują, wytwarzają i dystrybuują zasoby naturalne i inne, w procesie wytwarzania i reprodukcji ich życia biologicznego i społecznego. Aktywności te nigdy nie są izolowane od innych cech życia w społeczeństwie, zarówno prywatnych, jak i publicznych. Wszędzie bowiem wpływają i odzwierciedlają dystrybucję władzy, strukturę społeczną i instytucje kultury oraz ideologii w społeczeństwie lub mniejszych grupach wchodzących w jego skład ${ }^{16}$.

Twierdzi zatem, że

polityka jest uniwersalnym i przenikającym wszystko aspektem ludzkiego zachowania i można ją znaleźć wszędzie, gdziekolwiek dwie lub więcej istot ludzkich angażuje się w jakąkolwiek aktywność zbiorową, formalną czy nieformalną, publiczną czy prywatną ${ }^{17}$.

Argumentuje również, że polityka jest „przymiotem wszystkich ludzkich grup, instytucji i społeczeństw, a nie tylko niektórych spośród nich: polityka była zawsze i zawsze będzie" 18 . Nieuchronnie polityczne są więc w jego przekonaniu relacje kształtujące się na poziomie mikrostruktur społecznych, jak związki rodzinne, zawodowe, relacje konsty-

14 J. Rancière, op. cit., s. 86.

15 W takich kontekstach Rancière posługuje się terminem „beyond”, jak np. w Dis-Agreements. Politics and Philosophy (s. 85).

16 A. Leftwich, The Political Approach to Human Behaviour: People, Resources and Power, [w:] What is Politics?..., s. 100.

17 Ibidem, s. 103.

18 Ibidem. Ściśle analogiczne stanowisko, które również można uznać za panpolityczne, w polskiej literaturze przedmiotu sformułował A. Chmielewski w: Polityka jako przedmiot dociekań filozoficznych, „Przegląd Filozoficzny - Nowa Seria” 2016, nr 1 (97), s. 161-177. 
tuujące małe wspólnoty, na makropoziomie zaś przypisuje przymiot polityczności takim strukturom, jak związki i organizacje państw, Bank Światowy, Unia Europejska i inne ${ }^{19}$.

Ten sposób rozumienia polityczności w pełni zasługuje na miano panpolitycznego. Warto zwrócić uwagę, iż nosi ono również silne znamiona inspiracji Arystotelesowskich. W duchu Arystotelesowskim Leftwich pisze o „zasadniczo politycznej naturze wszystkich form zbiorowego zachowania ludzi” ${ }^{20}$. Co więcej, w omawianym stanowisku można również dostrzec inspiracje myślą Foucaulta, według którego polityka przejawia się także w mikrostrukturach społecznych.

Istotną konsekwencją przytoczonego stanowiska jest to, że takie rozumienie relacji między polityką a rozmaitymi formacjami społecznymi nakazuje postrzegać politykę jako po prostu sferę ukonstytuowaną w celu zarządzania wszelkimi typami społeczeństw. Inną, nie mniej ważką, konsekwencją tego stanowiska jest to, że polityka służy przede wszystkim zarządzaniu konfliktami, jakie nieuchronnie pojawiają się na płaszczyźnie każdej formacji społecznej. Innymi słowy, przytoczone panpolityczne rozumienie polityki wskazuje na nieuchronny związek polityki i konfliktu społecznego. Na mocy zaproponowanej przez Leftwicha definicji bowiem polityka jest przymiotem wszystkich ludzkich aktywności: konfliktu, negocjacji i współpracy w sposobach wykorzystywania, wytwarzania i rozdziału zasobów.

\section{Konkluzja}

Konfrontacja między marksizmem a przedstawioną koncepcją polityki Leftwicha wskazuje, że na gruncie marksizmu nie do przyjęcia jest stanowisko panpolityczne, które przypisuje polityczność nie tylko państwowości, ale także wszystkim mikro- i makrostrukturom społecznym. Podsumowując skrótowo krytykę przyjętej na gruncie marksizmu tezy o rozłączności konfliktu i polityki, należy uznać ją za nietrafną głównie ze względu na fakt niehistorycznego utożsamienia polityki z państwem. Można bowiem przyznać rację przedstawicielom tej doktryny, iż wszelkie formy państwowości mogą ulegać transformacjom, a nawet całkowitej atrofii, „zniesieniu” lub przeniesieniu na wyższe poziomy, jak sojusze czy związki ponadpaństwowe. Podobnie można zaakceptować tezę o zniesieniu konfliktu klasowego. W istocie jesteśmy obecnie świadkami „zniesienia” klasy robotniczej w jej tradycyjnym, Marksowskim znaczeniu. Mimo to nie ma podstaw do uznania, że z tych transformacji wynika możliwość zniesienia konfliktu społecznego czy kres polityki. Co do pierwszej kwestii, tj. niemożliwości zniesienia konfliktu jako takiego, zgadzają się na to sami zwolennicy marksizmu. Co do kwestii drugiej, mianowicie zniesienia polityki, za przekonującą należy raczej uznać tezę o wszechobecności polityki jako przymiotu wszelkich aktywności ludzkich, zorientowanych na wytwarzanie i rozdział zasobów ludzkich, dokonujących się na rozmaitych poziomach

19 Na ten temat por. A. Jabłoński, Węzłowe zagadnienia teorii polityki, „Studia z Teorii Polityki” 1, 1999, oraz A. Czajowski, Decydowanie w polityce, Wrocław 2013, s. 32-39.

20 A. Leftwich (op. cit., s. 114) pisze o: „[i]ntrinsically political nature of all collective human behaviour”. 
życia społecznego. Wynika bowiem z niej także wniosek o konieczności rozwiązywania sporów i konfliktów, jakie w nieuchronny sposób procesy te generują. Wniosek ten przesądza na rzecz ścisłego związku między konfliktem i polityką oraz na rzecz tezy, że polityka jako sfera i metoda rozwiązywania konfliktów jest nieodłączną cechą wszelkich form życia społecznego.

\section{Bibliografia}

Callinicos A., Marxism and Politics, [w:] What is Politics? The Activity and Its Study, red. A. Leftwich, Polity Press, Cambridge 2004.

Chmielewski A., Polityka jako przedmiot dociekań filozoficznych, „Przegląd Filozoficzny — Nowa Seria” 2016, nr 1 (97), s. 161-177.

Czajowski A., Decydowanie w polityce, Wrocławskie Wydawnictwo Naukowe Atla 2, Wrocław 2013.

Czajowski A., X twierdzeń o polityce, Wydawnictwo Adam Marszałek, Torun 2015.

Fukuyama F., Koniec historii, przeł. T. Bieroń, M. Wichrowski, Zysk, Poznań 1996.

Fukuyama F., Ostatni człowiek, przeł. T. Bieroń, Zysk, Poznań 1997.

Jabłoński A., Węzłowe zagadnienia teorii polityki, „Studia z Teorii Polityki” 1, 1999, s. 9-30.

Leftwich A., The Political Approach to Human Behaviour: People, Resources and Power, [w:] What is Politics? The Activity and Its Study, red. idem, Polity Press, Cambridge 2004.

Marks K., W kwestii żydowskiej, [w:] K. Marks, F. Engels, Dzieła, t. 1, Książka i Wiedza, Warszawa 1960.

Rancière J., Dis-Agreements. Politics and Philosophy, przeł. na ang. J. Rose, University of Minnesota Press, Minneapolis-London 1999.

Žižek S., Przekleństwo fantazji, przeł. A. Chmielewski, Wydawnictwo Uniwersytetu Wrocławskiego, Wrocław 2001.

\section{Ubiquity of conflict, unavoidability of politics}

Keywords: definition of politics, political conflict, meta-politics

\section{Summary}

The aim of this paper is to outline an argument in support of a thesis asserting an intimate relationship between a conflict and politics. I begin with a criticism of the claim that a conflict and politics are related to each other in a contingent and incidental way only. My criticism is aimed against the Marxist perspective in understanding politics which may be understood as radically anti-political one. For, despite stressing the unavoidability of social conflicts, Marxists claim that politics is a historical phenomenon and will be abolished together with the abolition of the state. Main weakness of this approach is that it is based on the identification of politics with the interest of the state institutions; in this way Marxism delimits the scope of politics to the level of state institutions only. I consider this delimitation unfounded and I invoke a pan-political conception of politics, formulated by Adrian Leftwich, who points out to the political nature of micro and macro structures of society. 


\section{Informacja uzupełniająca}

Informujemy, że tekst autorstwa Doroty Drałus, Endemiczność konfliktu, nieuchronność polityki, opublikowany w t. 22 (2017) pisma, powstał w ramach realizacji projektu Narodowego Centrum Nauki nr 2013/09/B/HS1/00362.

Erratę przygotowano na prośbę Autorki.

Redakcja „Wrocławskich Studiów Politologicznych”

„Wrocławskie Studia Politologiczne” 22, 2017 